\title{
Edukasi Perawatan Jenazah dan Perbaikan Fasilitas Pemakaman
}

\author{
Edi Hartono1, Burhan Barid², Willis Diana3, Sumadi4 \\ 1,2,3 Program Studi Teknik Sipil, Fakultas Teknik, Universitas Muhammadiyah Yogyakarta, Yogyakarta, Indonesia \\ Jl. Brawijaya, Geblagan, Tamantirto, Kasihan, Bantul, Yogyakarta \\ (0274) 387646 ext.232, 087734004455 \\ Email: edi.hartono@umy.ac.id \\ DOI: $10.18196 / \mathrm{ppm} .32 .198$
}

\begin{abstract}
Abstrak
Pengetahuan tentang perawatan jenazah sesuai sunnah masih kurang dipahami oleh sebagian masyarakat. Masyarakat di desa biasanya lebih menggantungkan prosesi perawatan jenazah kepada seorang modin. Kendala sering terjadi bila modin tidak berada ditempat saat ada orang meninggal sehingga perawatan jenazah agak tertunda. Kebiasaan di masyarakat dalam prosesi pemakaman juga masih dipengaruhi oleh adat yang kurang selaras dengan ajaran agama. Bangunan makam di area dengan elevasi yang lebih tinggi biasanya memerlukan bangunan penahan tanah untuk mencegah longsor. Fasilitas pendukung pemakaman, seperti keranda dan tempat memandikan jenazah, terkadang tidak layak. Latar belakang tersebut yang mendasari dilaksanakannya program pengabdian masyarakat di Kampung Kadirojo, Desa Jamus Kauman, Kecamatan Ngluwar, Kabupaten Magelang, Provinsi Jawa Tengah. Kegiatan ini bertujuan untuk memberikan edukasi kepada warga masyarakat tentang perawatan jenazah sesuai sunah, membantu desain keranda jenazah, serta merencanakan \& menstimulasi pembangunan dinding penahan tanah area pemakaman. Metode penyampaian dalam edukasi perawatan jenazah dilakukan dengan paparan dan tanya jawab tentang materi cara memandikan, cara mengkafani, dan cara menguburkan jenazah. Perancangan / desain keranda jenazah \& dinding penahan tanah dilakukan oleh Tim Pengabdian Masyarakat Universitas Muhammadiyah Yogyakarta. Kegiatan kajian pembimbingan jenazah telah dilaksanakan pada tanggal 25 Juli 2020. Warga sangat antusias dengan kegiatan dan berharap kegiatan pengabdian dapat secara kontinyu dilaksanakan. Hasil desain keranda jenazah telah disampaikan ke ketua rukun kampung. Stimulasi dana dari LP3M UMY berhasil menggugah pendanaan swadaya masyarakat dalam pembangunan dinding penahan tanah. Proses pembangunan tertunda karena pandemi virus Covid-19.
\end{abstract}

Kata Kunci: edukasi perawatan jenazah, perbaikan fasilitas, desain keranda, penahan tanah, stimulus

\section{Pendahuluan}

Salah satu tuntunan syariat Islam yang telah diajarkan oleh Rasulullah SAW ialah perawatan jenazah. Menyelenggarakan perawatan jenazah bagi umat Islam hukumnya fardu kifayah. Fardu kifayah artinya apabila telah ada seseorang atau beberapa kelompok orang telah melaksanakan kewajiban tersebut, gugurlah kewajiban orang lain untuk melaksanakannya. Empat fadu kifayah yang dilakukan untuk jenazah itu ialah memandikannya, mengkafaninya, menshalatkannya, dan menguburkannya (Riyadi, 2019). Namun, pada kenyataannya, sebagian masyarakat masih belum memiliki pengetahuan yang benar mengenai tata cara merawat jenazah yang sesuai dengan sunah (Misran, 2014).

Dusun Kadirojo merupakan lokasi pengabdian masyarakat dalam edukasi perawatan jenazah. Dusun ini berada di Desa Jamuskauman, Kecamatan Ngluwar, Kabupaten Magelang Jawa Tengah. Lokasi ini berjarak 21,6 km dari UMY (Gambar 1). Program ini dilakukan mengingat masih adanya masyarakat yang kurang memahami apa yang seharusnya dilakukan dalam perawatan jenazah sesuai sunah. Mereka hanya melakukan perawatan jenazah berdasarkan kebiasaan turun temurun yang kental dengan budaya dan terkadang masih berhubungan dengan hal-hal tahayul, seperti untuk mensucikan jenazah, air yang digunakan harus dari 7 air ( 7 sumur), melempar uang dan menyapu jalan rute pemakaman, berjalan mengitari jenazah 7 kali sebelum dimakamkan dan lain-lain. 


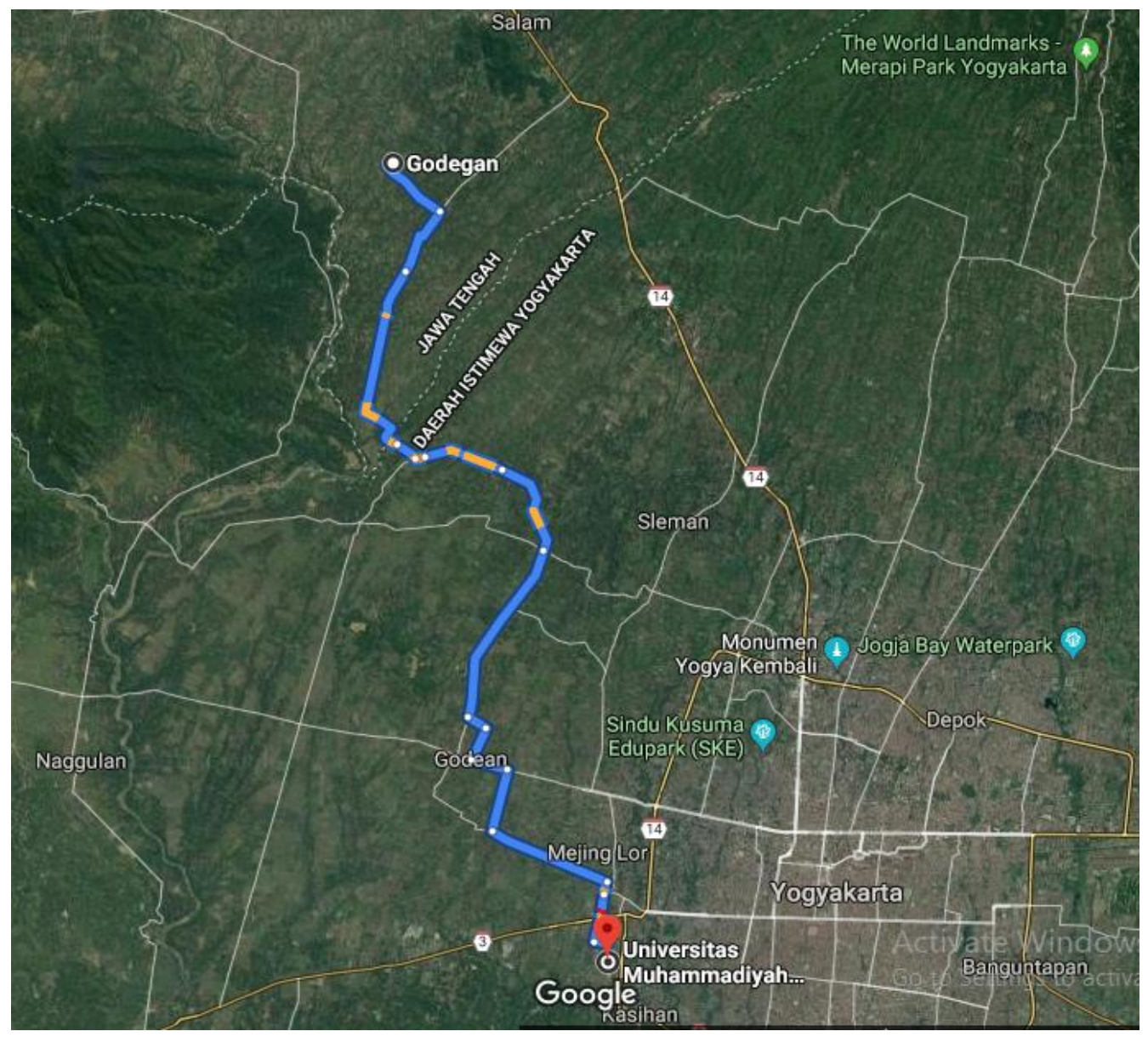

Gambar 1. Lokasi letak dusun Kadirojo

Kurangnya pengetahuan dan pelatihan dalam hal perawatan jenazah menyebabkan masyarakat cenderung menunggu orang yang terbiasa dalam hal pengurusan jenazah, yaitu modin. Hal tersebut menjadi kendala manakala modin tidak berada di tempat dan dalam waktu yang hampir bersamaan ada beberapa orang yang meninggal dunia. Di samping hal tersebut, modin juga hanya mendapat pengetahuan secara otodidak atau tidak pernah mendapatkan pelatihan. Pengurusan jenazah sebenarnya menjadi kewajiban keluarga terdekat si mayit. Kalau keluarga yang terdekat tidak ada, barulah orang muslim yang lainnya berkewajiban untuk merawatnya (An-Nabawi, 2018).

Bangunan makam yang berada pada elevasi yang lebih tinggi seringkali mengalami longsor, terutama pada musim penghujan. Penguatan lereng dengan dinding penahan tanah diperlukan untuk mencegah kelongsoran. Fasilitas perawatan jenazah juga merupakan faktor penting terselenggaranya perawatan jenazah yang syar'i. Kurangnya fasilitas yang memadai, seperti tidak adanya bilik portabel untuk memandikan jenazah, membuat masyarakat terkadang melakukan di halaman rumah, dengan tirai pembatas seadanya sehingga aurat dari jenazah terkadang dapat dilihat banyak orang. Fasilitas lain, seperti meja untuk memandikan jenazah. dilakukan memakai meja keranda yang sudah tidak layak.

Mengingat beberapa permasalahan di atas, perlu adanya kegiatan pelatihan perawatan jenazah yang benar sesuai tuntunan sunah Rasulullah SAW dari awal hingga akhir. Hal ini dilakukan agar jika suatu saat terjadi musibah meninggal dunia, banyak tenaga yang mampu mengurus jenazah dengan baik dan sesuai sunah Rasulullah SAW serta dapat menjauhkan masyarakat dari hal-hal yang berbau tahayul. Selain pelatihan, masyarakat Dusun Kadirojo juga memerlukan perbaikan bangunan makam dan membutuhkan desain pembuatan keranda jenazah yang memadai. 


\section{Metode Pelaksanaan}

Metode pelaksanaan dalam kegiatan pengabdian ini ialah melakukan pelatihan dan kajian tata cara perawatan jenazah sesuai sunah. Metode penyampaian dilakukan dengan paparan dan penggunaan video. Tanya jawab dan peragaan tentang materi perawatan jenazah dilakukan mulai dari cara memandikan, cara mengkafani, dan cara menguburkan jenazah. Program peningkatan fasilitas pemakaman dilakukan dengan membuatkan desain keranda jenazah. Untuk perbaikan bangunan makam, tim Pengabdian UMY memberikan desain dinding penahan tanah dan stimulus dana untuk menggugah swadaya masyarakat.

\section{Hasil dan Pembahasan}

Pelatihan pengurusan jenazah di Dusun Kadirojo dilaksanakan melalui beberapa sesi, yaitu: pertama, studi pendahuluan. Studi pendahuluan ini dilakukan sebagai tahap awal dalam kegiatan ini. Tujuan dari studi pendahuluan ini adalah untuk mengetahui sejauh mana pengetahuan peserta tentang pengurusan jenazah. Dengan mengetahui pemahaman peserta tentang tata cara pengurusan jezanah, hal ini akan memudahkan narasumber dalam menyampaikan materi yang sesuai dengan kemampuan mereka. Selain itu, bimbingan dalam bentuk ceramah, praktik mensucikan, dan mengafani jenazah juga dilakukan. Penyampaian materi dilakukan oleh Ustaz Asep Setyawan S.Th.I., M.Ud dari LPPI UMY dan moderator oleh Bapak Edi Hartono (Gambar 2).

Tata cara perawatan jenazah disampaikan mengikuti sunah Nabi Muhammad SAW. Perawatan jenazah juga harus mengikuti petunjuk dokter sesuai dalam putusan Majelis Tarjih dan Tajdid Muhammadiyah (Tarjih, 2012), terutama tata cara memandikan jenazah yang terkena penyakit menular agar tidak menimbulkan bahaya bagi yang memandikannya, seperti menggunakan sarung tangan, baju, dan mengacu pada protap (protokol tetap) tata cara memandikan jenazah penderita penyakit menular.

Majelis Tarjih dan Tajdid Muhammadiyah pada mulanya dinamai dengan Majelis Tarjih yang berasal dari kata rajjaha - yurajjihu - tarjihan yang bermakna mengambil sesuatu yang lebih kuat dari dua atau lebih pilihan yang ada. Penyebutan tarjih juga merupakan pengambilan dari salah satu metode dalam cabang ilmu Ushul Fiqh yang memiliki makna 'usaha yang dilakukan oleh mujtahid untuk mengemukakan satu yang dianggap paling kuat di antara dua dalil yang saling bertentangan karena dianggap memiliki kelebihan yang lebih kuat dari yang lainnya'. Oleh karena itu, tarjih dalam istilah persyarikatan Muhammadiyah sebagaimana terdapat pada uraian singkat mengenai "Matan Keyakinan dan Cita-cita Hidup Muhamadiyah" adalah usaha membandingkan pendapat dalam musyawarah kemudian mengambil alasan yang paling kuat karena dianggap paling sesuai dengan tuntunan Alquran dan as-Sunnah alMakbulah.

Pada tahap awal didirikannya, Majelis Tarjih, sesuai dengan namanya, hanyalah bertugas memilih antara beberapa pendapat yang ada dalam diskurusus hukum Islam, misal dalam fikih empat mazhab yang memiliki sekian banyak perbedaan pada ranah produk fikih, kemudian dipilih pendapat yang dipandang lebih kuat. Akan tetapi, karena perkembangan masyarakat dan jumlah persoalan yang muncul semakin kompleks, serta banyaknya persoalan-persoalan yang belum di temukan dalam khazanah pemikiran hukum Islam klasik, konsep Majelis Tarjih dan Tajdid Muhammadiyah mengalami pergeseran yang cukup signifikan menjadi usaha mencari ketentuan hukum terhadap segala permasalahan baru yang belum pernah dibahas ketentuan hukumnya di kalangan ulama terdahulu. Usaha-usaha tersebut di kalangan ulama Ushul Fiqh dikenal dengan "Ijtihad" (Iqbal dan Muhammad, 2015) 


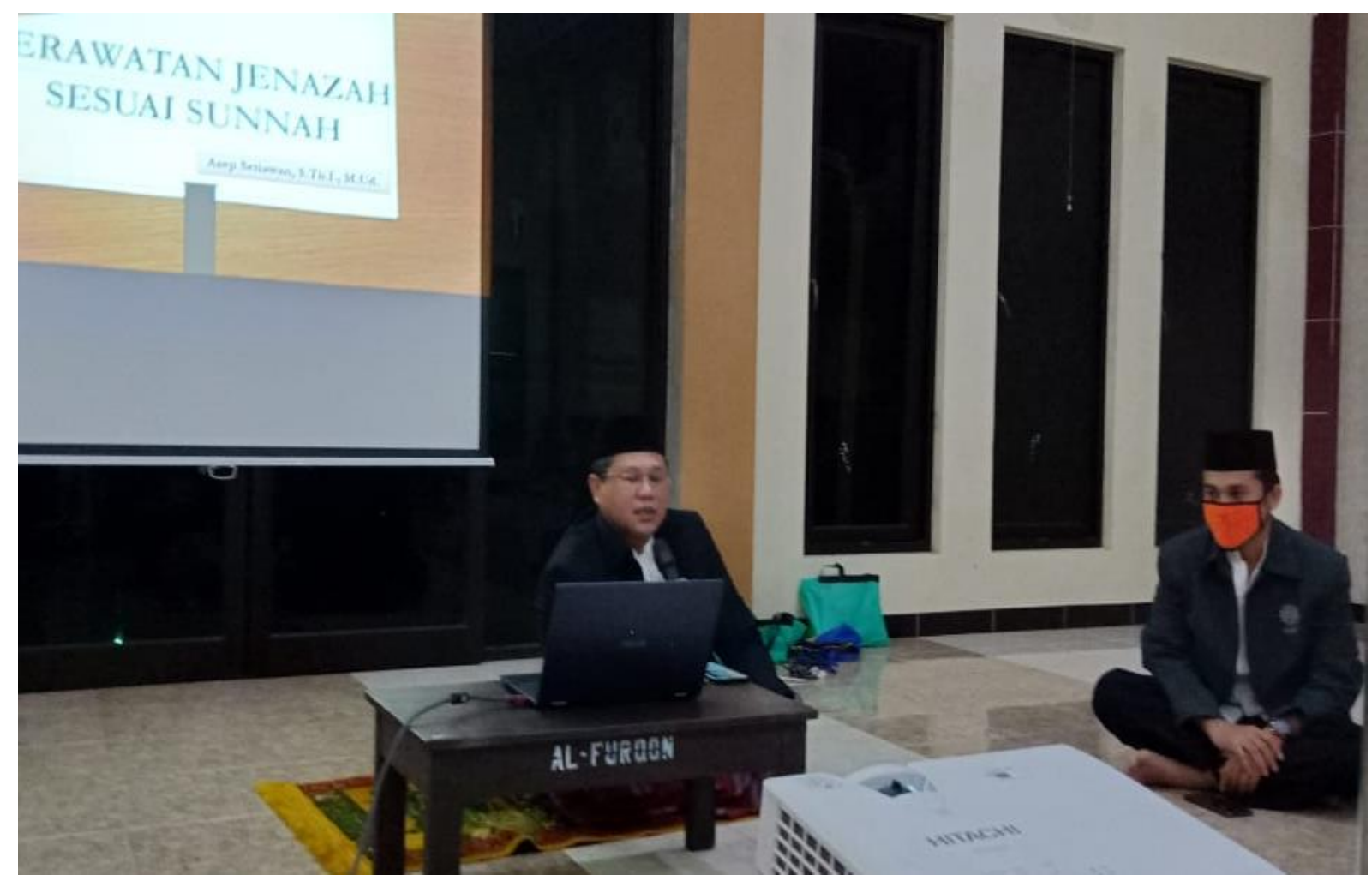

Gambar 2. Penyampaian materi tentang perawatan jezah sesuai sunnah

Warga sangat antusias dengan kegiatan yang diadakan. Mereka berharap kegiatan pengabdian ini dapat secara kontinyu dilaksanakan. Antusias masyarakat ditunjukkan dengan banyaknya masyarakat yang hadir dalam pelatihan seperti yang ditunjukkan pada Gambar 3. Selain pemberian materi dan praktik, masyarakat juga diberi kesempatan untuk bertanya mengenai hal-hal yang masih belum dipahami sehingga mereka nantinya benar-benar paham tata cara perawatan jenazah yang sesuai dengan petunjuk Nabi SAW dan mengikuti petunjuk dokter apabila jenazahnya memiliki penyakit menular.

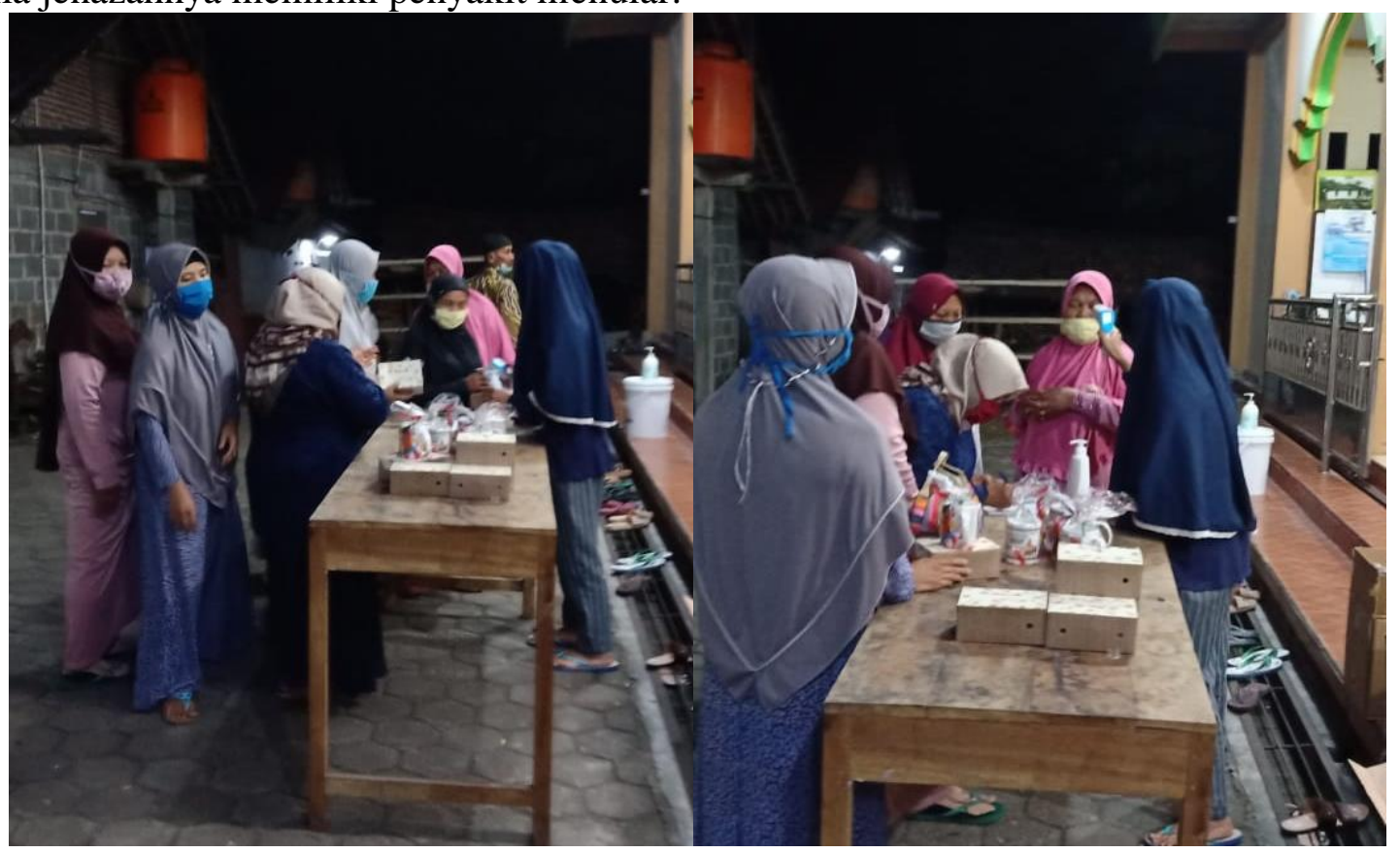

Gambar 3. Masyarakat di Dususn Kadirojo yang hadir dalam kajian \& pelatihan 


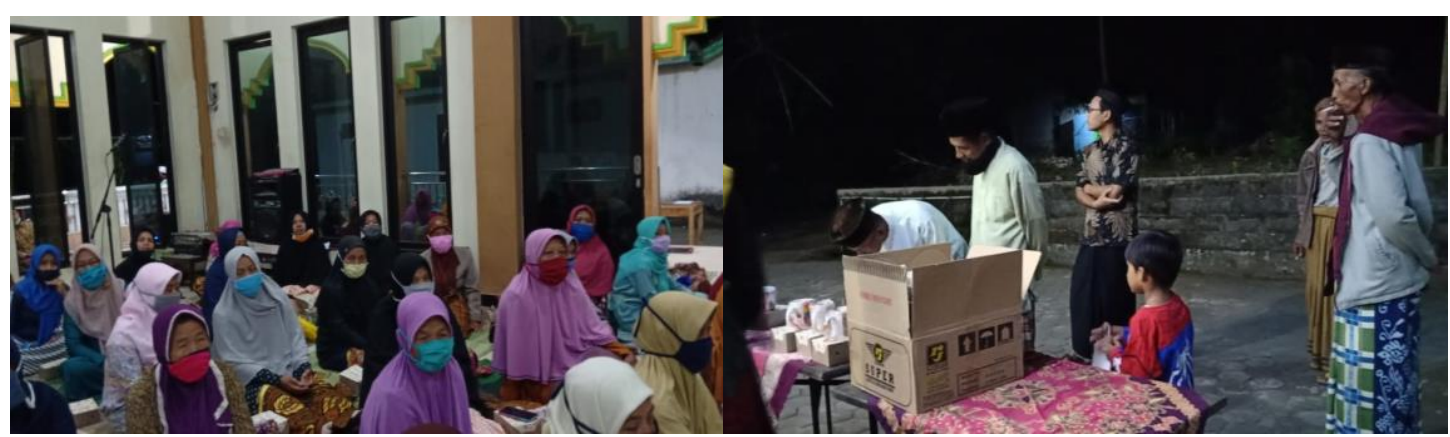

Gambar 4. Masyarakat di Dususn Kadirojo yang hadir dalam kajian \& pelatihan

Selain pengetahuan dan keterampilan, masyarakat Dusun Kadirojo juga memerlukan fasilitas yang memadai untuk perawatan jenazah. Mengingat kondisi keranda jenazah yang ada sudah cukup usang dan berumur, perlu dilakukan perbaikan, baik dari segi bahan maupun sisi desain, agar bisa digunakan sekaligus sebagai meja tempat memandikan jenazah yang layak.

Untuk memperbaiki fasilitas perawatan jenazah, tim pengabdian memberikan desain keranda jenazah yang lebih modern, praktis, dan tahan lama. Pada Gambar 4, dapat dilihat desain keranda yang akan dibuat. Desain keranda ini terdiri atas meja untuk menyucikan jenazah sekaligus terdapat keranda yang digunakan untuk membawa jenazah sampai ke liang lahat. Bahan yang digunakan berasal dari stainless steel yang kuat. Tujuannya adalah agar keranda tersebut dapat digunakan dalam jangka waktu yang lama. Gambar desain hasil perancangan dinding penahan tanah dapat dilihat pada Gambar 5. Struktur dinding penahan tanah terbuat dari batu kali dan beton bertulang. Struktur dari batu kali dipilih dengan mempertimbangkan sumber daya masyarakat dan alam sekitar. Dusun Kadirojo berada dekat dengan lokasi quarry pasir dan batu kali, yaitu Sungai Krasak dan Sungai Blongkeng sehingga dari sisi harga lebih murah. Sebagai penguatan dibuat kombinasi dengan beton bertulang pada setiap jarak tiga meter. Stimulus dana dari LP3M berhasil menggugah masyarakat untuk swadaya dalam pembangunan dinding penahan tanah makam. Namun, pelaksanaan masih terkendala akibat pandemi virus Covid-19.
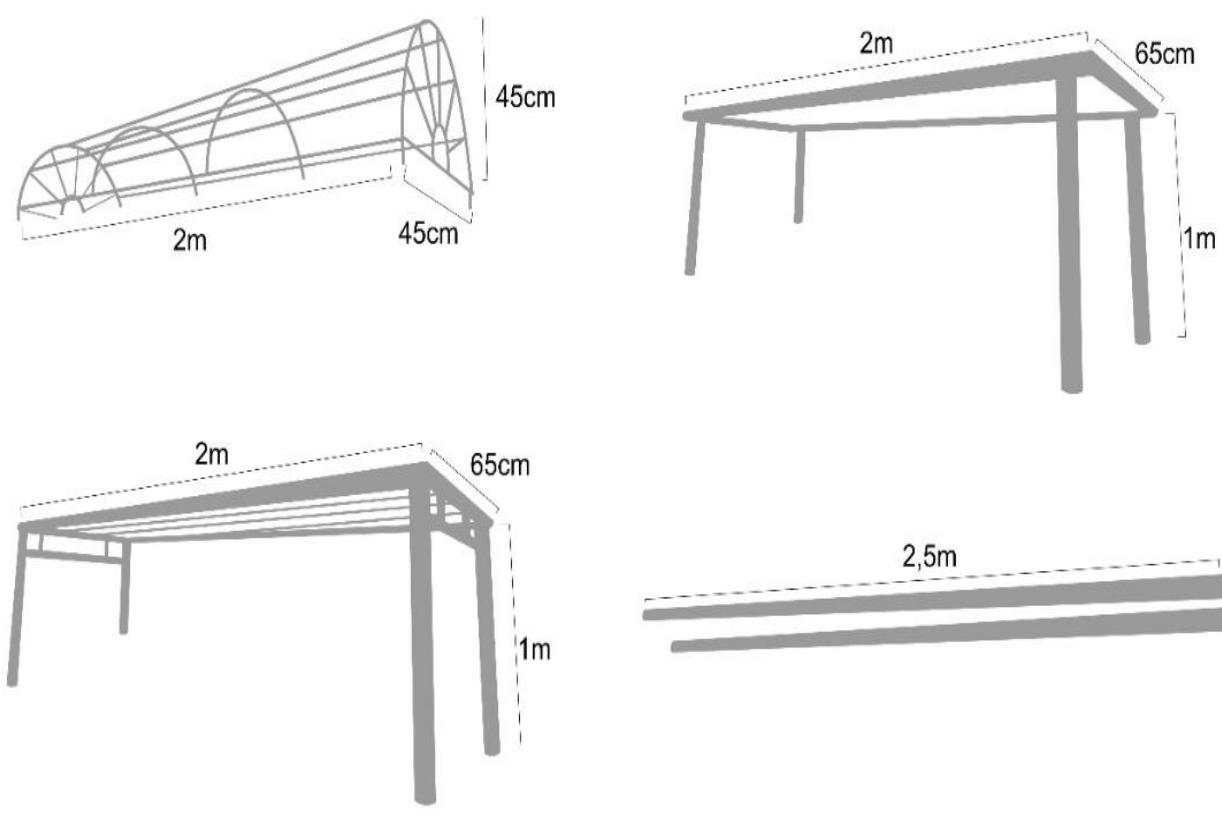

$2,5 \mathrm{~m}$ 


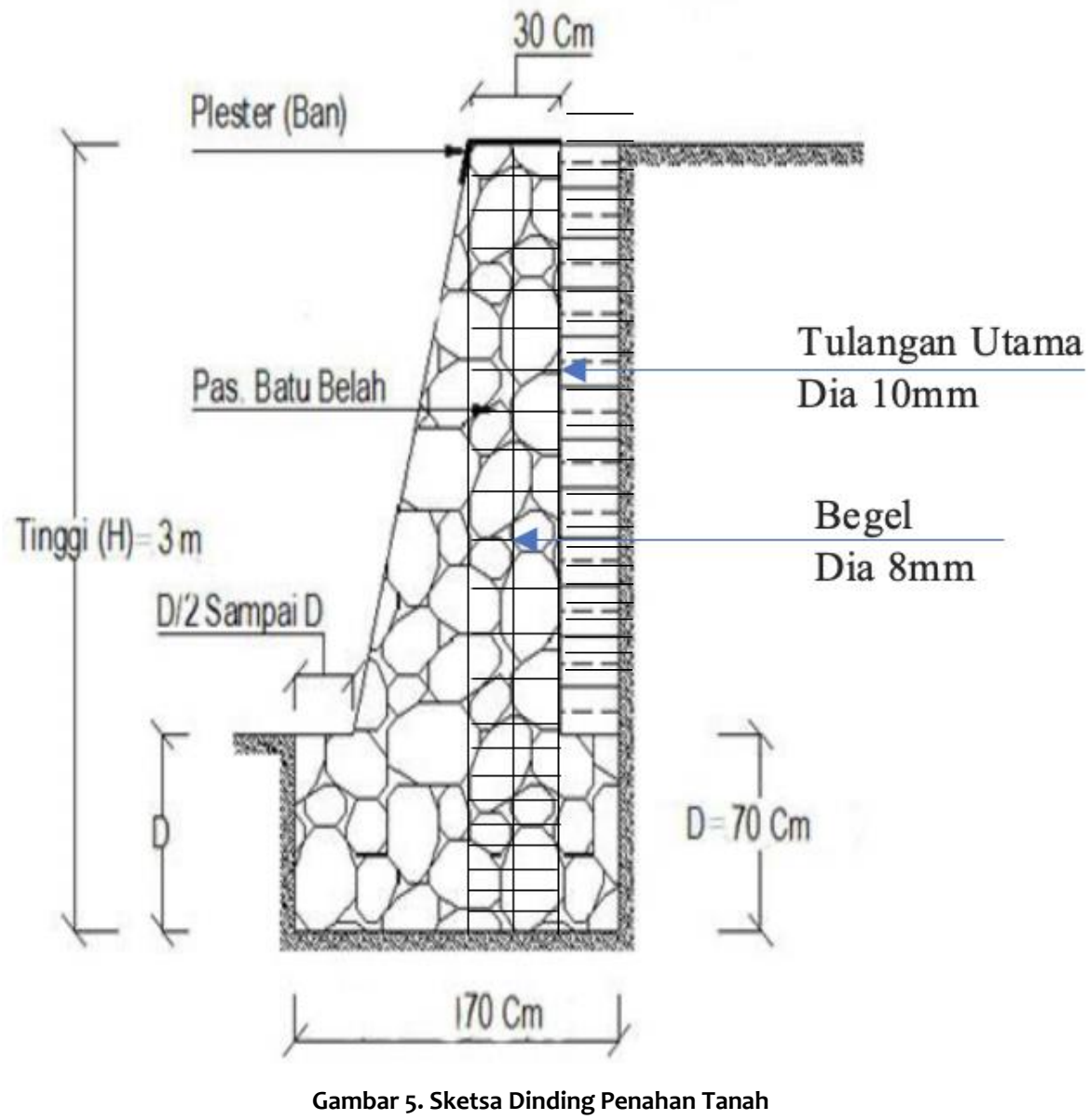

\section{Simpulan}

Kesimpulan dari kegiatan pengabdian ini adalah sebagai berikut.

1. Pelatihan pengurusan jenazah di Dusun Kadirojo terdiri atas penyampaian materi mengenai perawatan jenazah menurut sunah Nabi SAW dan tata cara menurut dokter apabila jenazah memiliki penyakit menulat. Masyarakat sngat antusias dalam mengikuti kajian / pelatihan.

2. Pengabdian ini memberikan bantuan, yaitu berupa pembuatan desain keranda yang terbuat dari bahan stainless steel dan bisa berfungsi sebagai meja untuk memandikan jenazah.

3. Pembuatan desain dinding penahan tanah mempertimbangkan sumber daya masyarakat dan alam sekitar. Stimulus pendanaan berhasil menggugah swadaya masyarakat.

\section{Ucapan Terima Kasih}

Ucapan terima kasih kami ucapkan kepada LP3M atas pendanaan dan dukungan dan kegiatan ini. Pengabdian ini merupakan skema PKM dengan kontrak No. 031/PENLP3M/I/2020. Ucapan terima kasih juga kami berikan kepada Bapak Ramelan, S.Pd. selaku Ketua Rukun Kampung Kadirojo dan Bapak Zuhri Ashari selaku Ketua Takmir Masjid AlFurqon Kampung Kadirojo, dan segenap masyarakat Rukun Kampung Kadirojo yang telah berpartisipasi dalam program ini. 


\section{Daftar Pustaka}

An-Nabawi, M.N, 2018, Pelatihan Keterampilan Penyelenggaraan Jenazah di Gampong Paya Beurandang Kecamatan Tanah Luas Kabupaten Aceh Utara, Prosiding Seminar Nasional Hasil Pengabdian 2018 IAIN Lhokseumawe.

Iqbal dan Muhammad, A.,2015. Pemikiran Pendidikan Islam, Pustaka Pelajar, Yogyakarta.

Misran, R, 2014, Implementasi dan Dampak Hasil Pelatihan Kaderisasi Penyelenggaraan Jenazah Muslim di Desa Bulota Kecamatan Telaga Kabupaten Gorontalo, Laporan Pengabdian Masyarakat, Jurusan Pendidikan Luar Sekolah, Fakultas Ilmu Pendidikan, Universitas Negeri Gorontalo.

Riyadi, A., 2019, Upaya Pemberdayaan dan Peningkatan Keterampilan Pemulasaraan Jenazah Di Wilayah Kecamatan Mijen, kota Semarang, Dimas Vol. 13 No. 2.

Tarjih, P. P. M. M, 2012, Himpunan Putusan Tarjih Muhammadiyah, Suara Muhammadiyah, Yogyakarta 